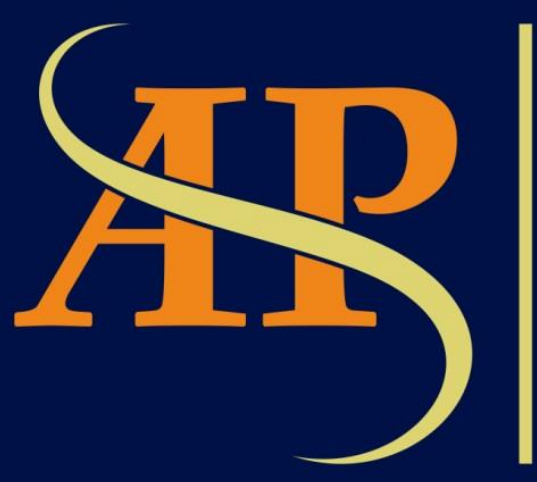

JURNAL

ASIA

PACIFIC

STUDIES

Journal of International Relations Study Program Faculty of Social and Political Sciences

Universitas Kristen Indonesia

Volume 2 | Number 2 | July - December 2018 


\title{
STATE AND GLOBAL SPORT GOVERNANCE: ANALYZING THE TRIANGULAR RELATIONSHIP AMONG THE FIFA, KEMENPORA RI, AND THE PSSI
}

\author{
Indra Kusumawardhana ${ }^{1}$, Muhammad Badaruddin ${ }^{2}$ \\ ${ }^{1}$ International Relations, Universitas Pertamina, Jalan Teuku Nyak Arief, Simprug, Grogol Selatan, Jakarta \\ Selatan, Daerah Khusus Ibukota Jakarta. \\ ${ }^{2}$ International Relations, Bakrie University, Jl. H. R. Rasuna Said No.Kav. C-22, Karet Kuningan, Kota Jakarta \\ Selatan, Daerah Khusus Ibukota Jakarta
}

kusumawardhana.up@gmail.com, muhammad.badaruddin@bakrie.ac.id

\begin{abstract}
Discussion on the power interplay between global sport governance and state-level sport management in Indonesia enriches discourse on the relation between globalization and nation-state's sovereignty. This Indonesia's case is an exceptional, since it is representing relationship among Fédération Internationale de Football Association (FIFA), the Indonesian Ministry of Youth and Sport (Kemenpora RI), and the Football Association of Indonesia (PSSI) which creates protracted dispute among football stake holders in Indonesia. This paper focus on the case of the Indonesian Kemenpora's decision to suspend the PSSI activities, which raised reaction of the FIFA by banning Indonesia's participation in the global football agenda managed by FIFA. Departing from the abovementioned context and perspectives, the purpose of this essay is to answer the questions about the significance of a nation-state's sovereignty to govern its domestic football issues, as well as answering the question of the global football governance's power over the national football association. In answering these questions, this paper will draw dynamics relation among domestic political powers which contribute to the internal dispute inside the PSSI in the first part. This paper will also portray the global context by describing on how the FIFA exercises its 'global authority' by imposing sanction to the member which is 'coopted' by the domestic political power for the second part. Finally, in the third part, this paper will discover the power interplay among these three actors until the recent progress of this case which seems to prove the effective power exercised by the FIFA as a global football governor.
\end{abstract}

Keywords: Global Governance, Nation-State, Football, Kemenpora RI, PSSI, FIFA.

\begin{abstract}
Abstrak
Diskusi mengenai interaksi kekuasaan antara tata kelola pemerintahan dunia di bidang olahraga dengan pranata manajemen olahraga pada level negara di Indonesia memperkaya diskursus terkait inter-relasi antara globalisasi dengan kedaulatan negara. Distingsi kasus Indonesia terletak pada interaksi triangular antara Fédération Internationale de Football Association (FIFA), Kementerian Pemuda dan Olahraga Republik Indonesia (Kemenpora RI), dan Persatuan Sepak Bola Seluruh Indonesia (PSSI) yang mengundang sengketa berkepanjangan antara pihak-pihak terkait dalam penyelenggaraan sepak bola di Indonesia. Artikel ini fokus pada dinamika pasca keputusan Kemenpora RI untuk melarang kegiatan PSSI, dimana keputusan tersebut memantik reaksi dari FIFA dengan membekukan hak partisipasi Indonesia di seluruh agenda sepak bola global yang dikelola oleh FIFA. Bertolak dari konteks dan cara pandang ini, tujuan utama dari artikel ini adalah untuk menjawab pertanyaan terkait signifikansi eksistensi kedaulatan negara dalam mengelola permasalahan sepak bola domestik, sekaligus mengungkap kekuasaan tata kelola sepak bola global terhadap asosiasi sepak bola nasional. Dalam menjawab pertanyaan ini, pada bagian pertama, artikel ini akan menelaah dinamika interaksi antara kekuatan-kekuatan politik domestik yang berkontribusi di dalam sengkarut kasus PSSI. Selain itu, artikel ini juga akan menangkap konteks global dengan mendeskripsikan kapasitas FIFA dalam mengartikulasikan otoritas global-nya dengan menjatuhkan sanksi terhadap anggota FIFA yang terkooptasi oleh kepentingan politik domestik. Sedangkan pada bagian akhir, artikel ini akan mengungkap interaksi kekuasaan antara tiga aktor di dalam kasus ini untuk membuktikan kekuasaan FIFA sebagai representasi dari "global football governor".
\end{abstract}

Kata kunci: Global Governance, Negara-Bangsa, Sepak Bola, Kemenpora RI, PSSI, FIFA. 


\section{Introduction}

30 Mei 2015, Fédération Internationale de Football Association (FIFA) officially impose sanctions to Indonesia. The punishment restricted Indonesia's national football team to contribute in international events. Moreover, the sanction also takes away the right of Football Association of Indonesia (PSSI) as national football governance body of Indonesia to accept generosity from FIFA and Asian Football Confederation (AFC) in a term of development and course fund (Republika.co.id 2015). This is a culmination from the unrelenting dissension of Football Association of Indonesia (PSSI) and Ministry of Youth and Sports of the Republic of Indonesia (Kemenpora RI) about the legitimacy to decide the future of Football in Indonesia. The dispute became publicly out after the appearance of KEMENPORA decree No 0137/2015 to freeze PSSI because of disobedience and indifference of action towards government (Republika.co.id 2015).

Ipso Facto, people of Indonesia is despiteful with the bitter sanction of FIFA to Indonesia because Football is a fiesta for the civil society at Indonesia. It has been years Indonesian people have not seen Indonesian national football team to be successful in international event for a long time because of its lack of achievement in the international events. Moreover, the dream of the people to see their national football team to become a champion in the international events is stranded by the fact that Indonesia's football organization which is PSSI too ignorance with the problem inside their body of organization and the condition of Indonesia's football league. Thereafter, because of the sanction from FIFA; Indonesian people must accept the reality that their national football team does not have right to compete in international events because the organization that has the authority to govern football events globally is dropping a sanction to Indonesia and freeze all the component of Indonesian League to run the game everywhere on earth until erratic time.

The bitter reality evoke an uproar from public; They accused Kemenpora RI as a representation of Indonesian government was intervening the authority of PSSI as the liason unit of FIFA in Indonesia to manage the football agenda in national scale. The uproar based on the legal standing of FIFA' Statutes that every football organization in national level as a member of FIFA organization is independence from any intervention from third party including national-government body. "To manage their affairs independently and ensure that their own affairs are not influenced by any third parties" (FIFA Statutes 2011, 13(g)). Furthermore, people of Indonesia justificate the dispute between Kemenpora RI and FIFA as a political drama in the context of struggle of power among elites to secure their interest as a regime. The whole uproar from public towards Kemenpora RI strengthen the position of PSSI as an organization in the Indonesian's national jurisdiction to hide behind the impendence of FIFA to drop sanction and cast away the Indonesian football from FIFA membership.

The whole process of the dispute was dramatize by the media, unfortunately public accept this with the limitation to digest in a clear understanding about the causality of the issue. At this point, there are two understanding that can be draw from the dispute between Kemenpora RI versus PSSI that leads into FIFA's sanction to Indonesia; (1) Indonesia as a nation-state with their sovereignty to control the institution beneath their jurisdiction is trying to impose an act to tackle the problem of their national football condition that motionless in under-accomplishment for along time. (2) The nature of this issue exposes a character of global governance behavior to nation state because the case of Indonesia's castigation by FIFA implicate the role of supra-national organization with a special authority to compel a policy towards nation-state. Based on this observation this paper found an interesting entry point to investigate this issue from International Relation point of view.

This paper departed from a simple question what is FIFA? How this organization could have a vigorous influence on the domestic institutions of a state, furthermore to play the 
back mind of the people of a nation to condemn its government because of fear for sanctions provided by FIFA. Prosecute a specific term and even force the state to follow the Code of Conduct (COC) and the regulations from an organization that if we see it from International Relations taxonomy is classified as an international non-governmental organizations (INGOs), which even has been transformed into a Private Governance. Based on a simple but very fundamental question; this study developed its curiosity to become the central question to be answered in this paper, which are: How FIFA weaken the sovereignty of a Nation State and legitimate its autonomy in the international system?

Start from an initial allegation based on critical awareness that FIFA as a global organization with a specific authority to take care football has the capacity to impose the sturdy law to Nation-State already becoming a hefty international organization. The argument of this paper will attempt to prove that the case occurred in Indonesia shows that FIFA has a veiled domination as an International Organizations which have sport sovereignty over Nation-State. The power to force Nation-State to obey in FIFA's code of conduct is the consequences of its function as the only global organization that regulate and facilitate a specific sport that is "football" (it is not politics between nations such as the United Nations or the regime of trade as WTO), it brings impression that FIFA is simply an organization that is far away from the political element and economic agenda. Moreover, the power of FIFA by using the popularity of football becomes a real challenge to the post-Westphalia models by cut in a line the state's sovereignty - in this context infiltrate the hierarchy of governments and kidnaping football from its domestic sovereignty.

The investigation of this paper will begin with an overarching view of the debate related to the global dynamics of private governance in the international system that became a cornerstone in strengthening preposition built through a claim to be stated in the hypothesis of this study. Then, an attempt to understand how FIFA plugging its unique position within the international system will be elaborated through the development of FIFA as an autonomous organization body in the world of international football and constructed its sport sovereignty in the Global scale. After knitting the whole knowledge by thorough literature review, the theoritical framework will be operationalized to do an empirical analysis that focus on a case Kemenpora RI versus PSSI and the role of FIFA in this problem.

\section{Theoritical Framework}

As has been previously disclosed; this paper will examine a variant of International Organizations which have not received much attention which is FIFA as representation of Global Private Governance in Football. Global Private Governance is generally regarded as a new phenomenon that is laden with nuances of neo-liberal globalization. (Dingwerth 2008) Although both international Olympic Committee (IOC), which was established in 1894 and the Fédération Internationale de Football Association (FIFA) that established in 1904 is much older than all the intergovernmental institutions much studied in the international relations discourse after World War II and contemporary globalization. In fact, the reality reveals that international sports has a sophisticated governance to maintain absolute claims regarding its autonomous nature from national government and public authorities (Chappelet 2010). Furthermore, the character of global sport law as transnational autonomous order created by the private global institutions has inspired legal scholars to compare the lex sportiva to the lex mercatoria (Foster 2003, 2).

On the dimensions of contemporary International Relations debates on governance have been at the heart of much of the literature on globalization and GVCs (For Instance, Held and McGrew 2002, Henderson et al. 2002, Dicken 2003, Gereffi 2005, Gereffi et al. 
2005, Coe et al. 2008). This paper is based on unrelenting literature debate about the implications of global governance as a concept to the concept of Nation - State as the core unit in international system, also as the main concept in international relations discourse. The long debate about this two concept produce an extensive paradigm; through the state-centric (by realism) and romantic accounts (by critical theory) to the present day "Enlightened Romantic" approach of social constructivism. Too bad, most of the discourse still focus on state as the sole actor to facilitate the dynamics of world affairs, global private governance in a specific field of authority like FIFA is not getting much attention from academic milieu. This is the reason why finding a theoretical foundation for the study of FIFA initially offered a challenge in the process to indite this paper.

Nonetheless, in order to dismantle the FIFA posture as Organization / Regime / International Institution in the field of football that showed a domination of the International Organization over countries that have a football organization in the national level should be based on the definition as an initial starting point. For the sake of this paper to gain a comprehensive understanding of FIFA as a special body organization; this study choose the definition of Keohane in the 1980s that has given the effort to elaborate a comprehensive concept in understanding the form Organization / Regime / International Institution. Keohane's description about this is as follow "persistent and connected sets of rules (formal and informal) that prescribe behavioral roles, constrain activity, and shape expectations. (Keohane 1989)". Based on Viotti, Paul R., and Mark V. Kauppi (2012); the definition of International Organization can manifest in this 3 (three) categories: (1) Formal Intergovernmental or Cross-national, Nongovernmental Organizations: these are purposive entities, bureaucratic organizations with explicit rules and missions. The United Nations is a prime example of the former, the International Committee of the Red Cross (ICRC) of the latter. (2) International Regimes: Institutionalized rules explicitly agreed upon by governments that deal with a particular set of issues. Examples would include the international monetary regime established in 1944 but adapted to changing circumstances since then, the Law of the Sea regime developed in the 1970s, and the various arms control agreements between the United States and the Soviet Union during the Cold War. (3) Conventions: Informal institutions (or customary norms and practices) with implicit rules and understandings. These implicit understandings allow actors to understand one another and coordinate their behavior. Not only do they facilitate coordination, but they also affect actors' incentives not to defect in those situations where at least in the short term it might be in their interest to do so. "Reciprocity" is an example of a convention-political leaders expect reciprocal treatment in international dealings, both positive and negative, and anticipate costs of one kind or another if they violate the convention. Diplomatic immunity is an example of a convention that existed for centuries before it was codified in formal agreements in the 1960s.

Based on the definition and categories were elaborated by Keohane, this paper proposes an understanding that the fundamental of FIFA included in category one (1) the nongovernmental organization. However, as a neoliberal institution FIFA has the power to regulate members even provide real sanctions as experienced by the PSSI and Indonesia as the Nation - State. It is remarkable force from FIFA to force submission from members to follow the prescribed rules, it is like a government with sovereignty. From this point, this article will discuss the private global governance that can indirectly associated with a sophisticated International Organization like FIFA. Since James Rosenau and Ernst - Otto Czempiel (1992) arouse the concept of governance by non-state actors; discussion about this concept has gained the attention of many scholars who interested in the study offered. According to Rosenau $(2002,72)$, the concept of global governance refers to social functions or processes that can be performed or implemented in a variety of ways at different times and places'. Furthermore, Doris Fuchs $(2002,11)$ took a bold specific definition by claiming that 
"the core of the global governance argument concerns the acquisition of authoritative decision-making capacity by non-state and supra-state actors". Researchers have investigated more varied forms of private coordination and argued that problem solving in economic and political life can be provided through a plethora of governance arrangements (Ronit 2001, 573). Examples of such new non-state authority include private interfirm regimes regulating entire markets, private standard-setting cooperation, transnational advocacy networks and illicit authorities (Dingwerth and Pattberg 2008, 193).

According to Claire Cutler, Virginia Haufler, and Tony Porter (1999), several factors account for the alleged rise of private authority or of non-state governance. First, private authority may be seen as an agent of public authority due to the explicit delegation of certain functions by the state. Implicit delegation in the form of state failures to provide public goods may similarly legitimate private authority, as can the recognition of special expertise, the impartial provision of demanded authority or tradition. Finally, neoliberal ideology might explain both the demand for private authority and compliance based on the perception that it is legitimate. Empirical case and the most obvious example in Indonesia is about AQUA as a company specialized in providing mineral water that if based on Indonesian constitution the water is supplied by the state as an essential public good or the phenomenon of ' polisi cepek ' who takes the role of police domain as an authority that should regulate traffic; it means commodification of the public sector is no longer a strange phenomenon in our daily lives.

Notwithstanding the multitude of non-state governance regimes it is often considered that such modes are embedded in hierarchical structures for which Renate Mayntz and Fritz Scharpf (1995) have coined the term 'shadow of hierarchy'. According to Tanja Börzel and Thomas Risse $(2010,116)$, the shadow of hierarchy 'means that the state threatens [...] to impose binding rules or laws on private actors in order to change their cost-benefit calculations in favor of a voluntary agreement closer to the common good rather than to particularistic self-interests'. However, this idea is at odds with the claim that the rise of powerful non-state actors in world politics might be challenging the authority of sovereign states (Sneding and Neumeier 2008, 654). Moreover, scholars have long argued that increasing opportunities for 'regime shopping' have enabled TNCs to impose their own rules on state governments (Biersteker 1980, Koenig-Archbugi 2004). Thus, it is far from clear to what extent governmental authorities can still exert some form of hierarchy over non-state actors. The case of football as a sector of major cultural and economic importance casts further doubts on the 'shadow of hierarchy'.

\section{Who rules the people's game?}

Football has been the world's most popular sport, Richard Giuliannoti (2004) convey this notion in his Journal "The globalization of football: a study in the glocalization of the serious life" that at least since the late nineteenth century and its international diffusion by the British. The 'global game' spans culturally diverse societies in all continents; an estimated 250 million people are direct participants, around 1.4 billion have an interest, 1 and football's flagship tournament, the World Cup finals, attracts a cumulative global television audience of 33.4 billion (Giuliannoti 2004, 1). For the sake of this notion a solid empirical data is available by Walvin (2001):

an estimated 250 million people are direct participants, around 1.4 billion have an interest, 1 and football's flagship tournament, the World Cup finals, attracts a cumulative global television audience of 33.4 billion. 2 Only relatively recently has the game's unparalleled cross-cultural appeal been realized financially. In 1998, football's world governing body, FIFA, 3 controlled contracts worth some $£ 4$ billion; by 2001, world football's turnover was estimated at around $£ 250$ billion, equivalent to the Netherlands' GDP (Walvin 2001). 
The illustration above shows how extensive the capital flow through this global sport, it is like flowing inside the vortex vein of human civilization to accumulate capital through global sport events; if it can draw conclusions about the figure of football in the world using Emile Durkheim typology about a form of contemporary culture; it can be said Football is a serious life.

As far as this paper can understand; Reality speaks that in the world of football knows only one international organization that has the authority to regulate everything that remotely to football agenda; FIFA is the sole authority body in the world with this special power to govern at the stage of global, regional and even national, this reality can be regarded as the representation of Global Governance in football. The utmost important substance to capture the implication of this obviousness is an impression that was built by FIFA as an international organization with the authority for governing the sport is making all forms of intervention against this organization is considered as an attempt to tarnish the sanctity of football as a sport that proclaimed to be the sport of the people who can unite the world and promote peace among nations and people. Consequently, it is understandable the problems that arise in the context of Kemenpora RI versus PSSI issue has become a problem that is very internalized personaly to the public in Indonesia. In this context we have to agree with the proposition of those who believe that Nation-State is weaken in the age of globalization; the fact that Indonesia is losing the control to regulate actor inside the border of its sovereignty strengthen the reality that globalization (in this case Globalization of Sport) become a grinding juggernauts for state sovereignty and diminish the capacity of the state in regulating institutions inside the country.

This view is consistent with what was said by Chaudhary (2005) on the definition of globalization "The processes throw which sovereign Nation-States crisis are crossed under mind by transnational actors with varying prospects of power, orientations, identities, networks" (Chaudhary 2005, 147). If it is allowed to state a joke, it is a trap for nation-state that already transpire for along time. Even worse state - every Nation that are members of FIFA perhaps are not aware of this reality because once again it is a matter of Football . ! The investigation presented in this paper will provide evidence that even private governance with a specific capacity only focus on providing social entertainment symbols in the context of this paper is football can dwarf the concept of nation - state and its sovereignty.

Departing from this point, we need to sit back for a moment that there is a substantial understanding in the discord of Kemenpora RI versus PSSI and FIFA predicament. Apparently, it is only some simple problems of football in the eyes of the public, it is perceptible far away from the affairs of a power struggle in the tradition of realism or the market driving forces in order to pursue the individual freedom in the context of liberal capitalist. Moreover, it is also to presumptuous if it is associated with the marxianstructuralism approach standpoint to capture the structure of its. However, we cannot turn away from the reality that the international system has led to various challenges that have weakened the legitimacy of the state. Although the robustness of the concept of the state and its sovereignty is still under debate, but the practice of modern statehood is still a practice that bases itself on a central idea of sovereignty. Which based under the Treaty of Westphalia in 1648, there are at least 3 (three) indicator which indicates a state has "Sovereignty": Firstly, have a clear boundary or territory; Secondly, Domestic Sovereignty, which has a government and various institutions that is responsible for the management of domestic life; Thirdly, External Sovereignty, where there is no other force that is higher than the state. Even though, some students of international politics take sovereignty as an analytic assumption, others a description of the practice of actor, and others as a generative grammar. This muddle part in fact still prove that sovereignty as an attribute of modern state still becoming a solid concept 
in international system. To capture the challenge that an international actor posed toward its concept is an interesting effort for international relation studies.

Many agree that the process of globalization creates an urge to form an international organizations as the representation of Global Governance framework (For Instance, Ruggie, John Gerrard. 1986, 1992, 1998, Finnemore, Martha. 1996, 2004, 2010, Held and McGrew 2002, Henderson et al. 2002, Dicken 2003, Gereffi 2005, Gereffi et al. 2005, Coe et al. 2008). But some scholars argues that the consequences of global governance is in some extent limited the state to exercise their authority because of the share norms, shared expectation and mutual recognition generated by international society in such mechanism, yet until now the argument is debatable because of the fact that the power of International Organization to regulate and even forcing a country to be subjugated toward an agreement or law is still questionable today. Ironically proposition like this does not apply to FIFA, what happened to Indonesia is a solid prove for the sturdy authority of FIFA to organize football. Furthermore, unconsciously football had been kidnapped from Nation - State domestic sovereignty. Is it fair for a country in the context of struggle to improve one of its institution quality? Where are the global democracy value in this unilateral decision?

\section{FIFA as International Football Governance}

Assumed that persistent international private governance regimes represent an institutional equilibrium whose stability results from the absence of pareto-improving alternatives (Calvert 1995a, b) in the case of FIFA the efficacy of the Westphalian doctrine of sovereignty can be reduced when the government by non - state actors can provide for the needs demanded by the public that the state itself does not have the capacity to provide a similar kindness. Moreover, in any moderately complex social context, institutional change requires considerable efforts (Dixit 2009, 19). FIFA as the only global organization with a privileged to manage football agenda even providing solution to increase the quality of football in each country members attribute with exceptional autonomy from any third party. Consequently, FIFA can impose a unilateral recognition to any national football team in this world is legit in the international stage only if the national government with the national football organization beneath it already submissive to FIFA's law. What if the submission is out of the table because of political intervention by the national government? The national government will face to face with the will of its people to see football as a fiesta. What happened to Indonesia is an empirical case of this theory; because Sport is prone to politicization because it can serve as symbol of cohesion and exclusion due to its dramatic and antagonist qualities (Giulianotti 1999).

FIFA's unique governance position results partially from the desirability of monopoly structures in sports. Most stakeholders of international sport, that is, athletes, sport federations, consumers, public authorities and commercial interests, gain the highest utility from 'meaningful' competitions (Neale 1964). Meaningful competitions require clear and consistent rules and regulations (Scully 1995), which are best provided by a regulatory monopoly. Moreover, due to stakeholders' interest in uncontested winners, there is also a need for monopoly structures in competitions. Thus, the unique contribution of international private governance regimes in sport consists of providing a 'definitional monopoly' for meaningful competitions. While the tasks of regulating and organizing competitions do not have to be bundled, FIFA acts as both global sport regulator and competition organizer giving FIFA total control over access to international football. This is the nature of FIFA, it is the real domination of an international organization with a unique position in international system. The irreplaceable contribution of FIFA already functionate for a long time, moreover 
the vehemence of FIFA authority is more wide after under the Joao Havelange leadership (1974s) FIFA spread it wings to the new emerging nation - states after the second world war. Bill Crane support this statement in his article "How FIFA ruined soccer"

FIFA as it exists today is the creation of its last president, João Havelange, who unseated Stanley Rous, long known for supporting apartheid soccer teams. After coming to power in 1974, Havelange presided over FIFA's transformation into a fully corporate structure, financed by sponsorship deals rather than contributions from national and regional federations. Under Havelange FIFA executed an unprecedented turn toward the nations of the Global South, which it had previously ignored but who were now international soccer's fan base. But the turn wasn't an inclusive gesture. It was designed to capitalize on business opportunities in rapidly growing countries like Mexico - where Havelange's associates were accused of bribery in connection with the 1992 World Cup and future Olympic games - and Brazil, where Swiss authorities estimated Havelange himself took over $\$ 50$ million in bribes during the 1990s.

FIFA organization that previously could be said to be a symbol of the power of the colonial empire and the axis of economic power of Europe finally riding the opportunities offered by globalization in accumulating capital through market expansion towards the whole world. These changes are accommodated by the momentum of decolonization after World War II that led to the emerging a new state as the consequences of nationalism to fight against colonial system. Although many who criticize capitalist interests are taken by FIFA, but the beauty of football still be a difficult offer to refuse by the people in any national government that has a national football passion. In this transformation Havelange's campaign was heavily supported by TNCs because his agenda implied a commercialization of international football (Sugden dan Tomlinson 1998b).

From this point; we can capture that the foundation of FIFA's governance as a nonstate actor with the ability to underplay territorial boundaries has two modality which are; firstly, the power of football as a global sport also as the symbol of cohesion among people in the world, then secondly the capital power from FIFA that supported by many parties with an interest to gain profit from the football competition all over the world. These two mode of power enforcing FIFA's uniqueness and manifest the capacity of FIFA to impose any law to any national government in this world. The irony of this fact is the nature of FIFA's governance as sophisticated as it is almost detached from critical spectacles of civil society in any nations. Only few already aware about this fact and stand against it.

The power of capital that supported by mammoth sponsorship of large multi-national corporations all over the world perpetuate the effectiveness of FIFA's power. It is also the backbone of FIFA's political legitimation to be an autonomous global private governance in this world. Because commercialization has further increased FIFA's importance as an arena of identity politics. Not only has FIFA's membership experienced a massive growth; improved revenues have also enabled FIFA to grant substantial development aid (Eisenberg 2006a, 2000b).

Refers to the recent data it reveals the extraordinary of capital accumulation obtained by FIFA, its myriad activity certainly generates an astonishing amount of revenue. The tax exempt non-profit organization, buoyed by success of the 2014 World Cup, generated a record $\$ 2$ billion in revenue. Compared to just 10 years ago, FIFA's revenue figures are extraordinary. In 2006, when Germany hosted the World Cup, revenue "only" amounted to $\$ 749$ million (McCarthy 2015). From here we can see that the accumulation of capital through the globalization of football make FIFA an independent and autonomous organization. In this condition FIFA officials freely distribute appropriate policies with the interests of FIFA against the national government that has football organizations as a member of FIFA. FIFA's executive is now capable of organizing majorities among the FAs by employing distributional 
policies (Eisenberg 2006a; Giulianotti and Robertson 2012) or even by resorting to "vote buying' (Tomlinson 2007).

On the other side, the international system that we live in today still grounded to Nation - State with its sovereignty system that if we choose to believe Hinsley (1966) argument that it began to grow in the 16th century and the 17th in two different meanings in niches of thoughts as the ruler understand. On the one hand, the authorities considered to be sovereign if there are no entities above or equal to nation-state as the legitimate body to govern based on territory. While on the other hand, the authorities can enjoy a sovereign state if there is no external challenge in the form of an international entity superiority over the territory that became the realm of sovereignty itself play. Until now , the question whether globalization has penetrated all aspects of contemporary human life has been weaken or strengthen the state's existence today still becoming a mainstream debate in International Relations discourse. The existence of FIFA gives us an insight If FIFA indirectly have abducted football from domestic sovereignty of a national government without reducing international support for its existence in arranging football, it can be said FIFA with the ability of governance which is claimed by the statutes of FIFA as a posture of governance which is autonomous from the authorities of any country has successfully establishes an imaginary sovereignty in the world of football that can be regarded as a sport sovereignty. Using the framework of governance of cross - border disseminated within the framework of continental authority, FIFA manifest its soverignty from any outside third parties in this world. Nation-State is out of jurisdiction to intervene in the imaginary sovereignty built by FIFA within the framework of the Global Governance football built by FIFA itself. FIFA Statutes be rules that strengthen the legitimacy of FIFA in regulating the nation-state in terms of football.

At this point, we concurred upon Henk Erik Meier and Borja Garcia (2015) that "FIFA is the umbrella organization of global football and has exhibited power to exert its autonomy by fighting undesirable legislation and even imposing its will over national governments. It has been able to make governments deviate from their own national regulation strategies in sports, which has proven to be a unique position of power for the organization. Whereas, Organizational hierarchy drawn through FIFA's sophisticated mechanism with trans-national governance cleavages at the level of continental, regional and national levels to make FIFA has the power to attract all the state-actors that want to fulfill the needs of its people to enjoy the beautiful game of football that are manifest in a dynamic national league or an opportunity to participate in international events. Therefore, we can see the process of how the power of FIFA has become a very sturdy framework for any country in this world. Some countries that do not comply with FIFA regulations must be prepared to get tough sanctions and dealing directly with public uproar over the lack compliance toward FIFA regulations. Indonesia is an example that proves empirically FIFA's iron regulation over nation-state. Given this reality the question that arises is whether all the nation-states in this world have the same conditions and problems? When the condition was not in accordance with the expectations of the national government as a sovereign entity, what kind of mechanisms to choose to fix the condition if the maneuver to make a change must deal with undemocratic regulation that seemed indifferent to domestic problems of a country like Indonesia?

\section{The Precipituous Road of Indonesia to Reform its National Football Governance}

Indonesian football is struggling to repair itself from the bars of decaying system that underlies this sport. This expression is not excessive, if we look for news depravity of football Indonesia through " google ", so many good cases of mafia of score fixing, athletes 
and coaches are not paid and etc. Poor achievement Indonesian football international arena is a reflection of the systemic problems that plagued indonesian football governance. Just like we can see in the article below:

\begin{abstract}
"Mafia had already control the world of football in Indonesia. This practice dismantled activists by reporting scandals defeat the national team for several matches. Head of Case Handling Jakarta Legal Aid Institute M. Isnur bring a record between bookie and score fixing actor that already systematically executed. He claims this practice occurred since the last 15 years. "We go to footage between bookies with regulators scoring in the match, " said M. Isnur Tempo, Tuesday, June 16, 2015. The report also brought Isnur to Police Headquarters."
\end{abstract}

"Indra Sjafri's voice suddenly caught in his throat. He poured mineral water from a plastic bottle into a glass, then taking his time slowly. Her eyes filled with tears. "please tissue," said Indonesia's national football coach U-19 to the class of Tjokroaminoto's committee for Nationality and Democracy at the room of Adi Sukadana Faculty of Social and Political Sciences, University of Airlangga, Saturday afternoon, November 30, 2013. After receiving a tissue, wiped her eyes, The atmosphere of the room instantly silent. About 200 students and faculty who attend college nationality was silent. Having managed to control her feelings, Indra continued exposure. "Finally we were able to get through a difficult period," he said.

About the dramatic feeling; Indra began when he got a question from a participant subjects: what did his wife think when she knows that Indra was not paid by the PSSI for 20 months? At the beginning of his presentation, Indra was explained that since given the task of handling the U-19 national team in September 2011, only 20 months later he received a salary. Whereas since decided to accept the offer to become coach, Indra leave his job as the head office of a company's State-Owned Enterprises in Padang. "For not paid, I was helped a friend. There are give debt, some give aid, "said the speaker Indra public lecture entitled nationalities together mental coach U-19 Guntur Cahyo Utomo."

The injustice displayed in the public media in Indonesia is already common in the world of football in Indonesia. Ironically, the Indonesian government has always deadlocked in order to interfere with the affairs of football that unilaterally claimed by PSSI as the affairs of the hierarchy directly below FIFA as the international organization in football. But we can see in FIFA's statutes article 2 subsection e already stated the objective of FIFA "to promote integrity, ethics and fair play with a view to preventing all methods or practices, such as corruption, doping or match manipulation, which might jeopardize the integrity of matches, competitions, Players, Officials and Members or give rise to abuse of Association Football." Too bad the reality is on the contrary of FIFA's objective. There are so many problems in this country relating to football, but FIFA itself seems to ignore all of the problem that has lasted so long in Indonesia. For example the condition of Indonesian football has been as severe as has been stated above do not make FIFA to act a concrete step in improving the quality of Indonesia's football governance. At this fact, this paper found disability from FIFA organization that are failed to facilitate the interest of its members, moreover the behavior of feudalistic hierarchy also appears in this case.

Under Imam Nahrowi; Kemenpora RI decision to conduct an action to response the condition of Indonesian football governance is beyond expectations of indonesian public. All of this time the people of Indonesia always worried about the FIFA's sanction reffering to the FIFA's statutes article 13 subsection 1 "to comply fully with all other duties arising from these statutes and other regulations." This article is a tough weapon to push back national 
government intervention towards football agenda. The article automatically poses a threat that any abrupt action will become unpopular policy by government. Indonesia is not alone in this problem; Greece, Spain and poland already face the sturdy regulation of FIFA earlier. The Indonesia's attempt to make a bold move to freeze PSSI as validly organization recognized by FIFA to organize football in Indonesia suffered a similar fate with the three countries stated previously. Imam Nahrowi as Minister of Youth and Sports (Affairs) obtain public blasphemy that incriminate the policy is based on lack of competence in understanding the mechanism of football holistically. But if we look at the severity of the problems that occur in the field of football in Indonesia and the long period of lack of achievement. This policy can be said to be a step that must be appreciated by the Indonesian public as a symbol of the presence of the State in domestic agenda, unfortunately, public face a difficulty in understanding the policy because of the threat of FIFA as an authority on international football to impose sanctions on Indonesia and the suspicion that this issue is a contestation between elite to preserve its power who do not even care about football. Based on our vantage point; it was like the nationalism of Indonesian people is disapear because of fear of the threat of international football authorities and requires the State to comply with the rules stipulated by FIFA. The public fear finally happened and FIFA sanctions are very hard to freeze all activities of the Indonesian football team and Indonesia even banned from playing throughout the event under FIFA as an international organization of football.

The development of this issue became more interesting when national government's policy to control domestic affairs that undertook by Kemenpora RI suddenly became a foreign policy when FIFA step up an make a unilateral decision to drop sanctioned towards Indonesia. Finally, to response the urge to deploy diplomatic acts towards FIFA, KEMENPORA RI form a small team to accomplish the interest of Indonesian government. It consist Indonesian expert on diplomacy such as the former ambassador of Indonesia for Swiss mr. Djoko Susilo, the former ambassador of Indonesia for the United Nations mr Makarim Wibisono, etc. Evidently, in the age of globalization that if we used the assumption by Giddens as the shrinking of the planet is a celebrated feature of contemporary globalization. (e.g. Giddens 1985, Held et al. 1999). Even farther using his definition "Globalization can thus be defined as the intensification of worldwide social relations which link distant localities in such a way that local happenings are shaped by events occurring many miles away and vice versa." It brings out a phenomena which is a national policy of a national government could be intervene by a non-state organization, moreover pose a threat to a national government and force to subjugated for a specific regulation. FIFA 's decision to impose sanctions over Indonesian football is an empirical prove for the position of skeptics towards Nation - State existence in the age of Globalization. FIFA domination over the nation-state in terms of football seen from a unilateral decision with no opportunity for KEMENPORA to sit in the same table with FIFA and negotiate the issue. Thus, this condition shows that the state has limitations in dealing with organizations like FIFA which are very influential globally.

\section{Conclusion}

Based on what has been narrated in this paper that FIFA has been unequivocal to preserve the autonomy of its authority in terms of football. More than just maintain its legitimacy as a non-state actor who have imaginary government, but also can force a sovereign government to bow down the path of national change for a better governance just like what happened in Kemenpora RI versus PSSI and FIFA. Borja (2012) arguments reinforcing the thesis of this paper that FIFA's domination is real towards national 
government Football makes evident that international multilevel private governance can develop efficient escalation mechanism allowing to 'move-up' local conflicts so that national governments face the whole power of a global monopoly regulator. National FAs chose to escalate conflicts by calling on FIFA to suspend them. Given the fact that a suspension would first harm the national FAs, their willingness to escalate indicates their confidence in FIFA's assertiveness. The cases proved this calculus valid. This paper also stated that the source of strength in the FIFA to impose rules in the world of football is a monopoly for access to international football competition run by FIFA and its sub-institutions that manifest in the continental, regional and national representation. Through this mechanism FIFA spread its sport sovereignty in the international system. In this case the non - compliance will result in reaction to the social and cultural of the people of a country, this reality makes no politician wants stigmatized by his own people as individuals that terminate the national football fate. In this problematic reality, these papers suggest a reconfiguration of behavior from FIFA to look carefully towards Indonesian football governance and work together with the government of Indonesia to reform its deficiency. The sanction for Indonesia from FIFA is the representation of injustice decision and ignorance behavior by international organization. More than just the act of arrogance but it is the notion of hegemony of FIFA as global governance towards Nation-State in the context of football. Why it is important to say this out loud? Because as a part of nation we must stand very clear where our hope for reformation should be placed, hope without clear and rigorous understanding about the constellation in a predicament posed a serious threat for logical fallacy. In this sense, this paper builds upon hope that it gives an alternative understanding for seeing the problem wisely. 


\section{REFERENCES}

\section{Books}

Chappelet, Jean Loup. 2010. Autonomy of Sport in Europe. Strasbourg: Council of Europe Publishing.

Chaudary, Ganga Dhar. 2005, Politics, Ethics, and Social Responsibility of Business, Paragon books.

Cutler, A. Claire, Virginia Haufler, and Tony Porter, eds. Private authority and international affairs. Suny Press, 1999.

Dicken, Peter. Global shift: Reshaping the global economic map in the 21st century. Sage, 2003.

Foster, Ken. "Is there a global sports law." Ent. L. 2 (2003): 2

Fuchs, Doris A. 2002. 'Globalization and Global Governance: Discourses on Political Order at the Turn of the Century.' In Transformative Change and Global Order: Reflections on Theory and Practice, ed. Doris Fuchs and Friedrich Kratochwil, Münster: LIT, 123.

García, Borja, and Henk-Erik Meier. "Keeping private governance private: is FIFA blackmailing national governments?." (2013).

Gereffi, Gary. "The global economy: organization, governance, and development." The handbook of economic sociology 2 (2005): 160-182.

Giddens, Anthony. The nation-state and violence. Vol. 2. Univ of California Press, 1985.

Giulianotti, Richard, ed. Sport and modern social theorists. Hampshire: Palgrave Macmillan, 2004.

Held, David, and Anthony G. McGrew, eds. Governing globalization: power, authority and global governance. Cambridge: Polity, 2002.

Held, David, et al. Global transformations, introduction. Cambridge: Polity Press, 1999.

Keohane, Robert Owen, and Joseph S. Nye. Power and interdependence: World politics in transition. 2nd ed. Boston: Little, Brown, 1977.

Keohane, Robert O. "International institutions and state power: Essays in international relations theory." (1989).

Krasner, Stephen D. Sovereignty: organized hypocrisy. Princeton University Press, 1999.

Mayntz. Renate and Fritz W. Scharpf. 1995. 'Steuerung und Selbstorganisation in staatsnahen Sektoren.' In Gesellschaftliche Selbstregulierung und Politische Steuerung, ed. Renate Mayntz and Fritz W. Scharpf. Frankfurt am Main: Campus, 9-38

Rosenau, James N. Turbulence in world politics: A theory of change and continuity. Princeton University Press, 1990.

Rosenau, James, and Ernst-Otto Czempiel. 1992. Governance without Government: Order and Change in World Politics. Cambridge: Cambridge University Press.

Scully, Gerald W. The market structure of sports. University of Chicago Press, 1995.

Sugden, John and Alan Tomlinson. 1998b. FIFA and the Contest for World Football: Who rules the People's Game? Cambridge: Polity

John Sugden and Alan Tomlinson. London, New York: Routledge, 61-80.

Sugden, John. 2002. 'Network football.' In Power Games: A Critical Sociology of Sport, ed.

Viotti, Paul R., and Mark V. Kauppi. International relations theory. Pearson Higher Ed, 2012. Walvin, James. "The Only Game." (2001). 


\section{Journals}

Börzel, Tanja and Risse, Thomas (2010). 'Governance without a state: Can it work?' Regulation and Governance 4(1), 113-134.

Cashore, Benjamin. 2003. Legitimacy and the Privatization of Environmental Governance: How Non- State Market-Driven (NSMD) Governance Systems Gain Rule-Making Authority. Governance 15(4), 503-529.

Coe, Neil M., Peter Dicken, and Martin Hess. "Global production networks: realizing the potential." Journal of economic geography 8.3 (2008): 271-295.

Dingwerth, Klaus and Philipp Pattberg. 2006. 'Global Governance as Perspective on World Politics.'Global Governance 12(2), 185-203.

Dingwerth, Klaus. 2008. 'Private Transnational Governance and the developing World: A Comparative Perspective.' International Studies Quarterly 52(3), 607-634.

Dixit, Avinash. 2009. 'Governance Institutions and Economic Activity.' American Economic Review 99(1), 5-24

Eisenberg, Christian. 2006b. 'FIFA 1975-2000: The Business of a Football Development Organization.' Historical Social Research 31(1), 55-68

García, Borja, and Henk Erik Meier. "Limits of interest empowerment in the European Union: The case of football." Journal of European integration 34.4 (2012): 359-378.

Gereffi, Gary, John Humphrey, and Timothy Sturgeon. "The governance of global value chains." Review of international political economy 12.1 (2005): 78-104.

Giulianotti, Richard, and Roland Robertson. "The globalization of football: a study in the glocalization of the 'serious life'." The British Journal of Sociology 55.4 (2004): 545568.

Giulianotti, Richard and Roland Robertson. 2012. 'Mapping the Global Football Field: A sociological Model of Transnational Forces within the World Game.' British Journal of Sociology 63(2), 216-240.

Henderson, Jeffrey, et al. "Global production networks and the analysis of economic development." Review of international political economy 9.3 (2002): 436-464.

Hinsley, Francis H. "The concept of sovereignty and the relations between states." Journal of International Affairs 21.2 (1967): 242-252.

Koenig-Archibugi, Mathias. 2004. 'Transnational Corporations and Public Accountability.' Government and Opposition 39(2), 234-259.

Meier, Henk Erik. 2008. 'Institutional Complementarities and Institutional Dynamics: Exploring Varieties in European Football Capitalism.' Socio-Economic Review 6(4), 99-133.

Henk Erik Meier and Borja García, "Protecting Private Transnational Authority against Public Intervention: FIFA's Power over National Governments", Public Administration, Vol. 93, No. 4 (2015), pp. 890-906.

Neale, Walter C. "The peculiar economics of professional sports: A contribution to the theory of the firm in sporting competition and in market competition." The Quarterly Journal of Economics (1964): 1-14.

Peters, B. Guy and Jon Pierre. 1998. 'Governance without Government? Rethinking Public Administration.' Journal of Public Administration, Research and Theory 8(2), 223243.

Ronit, Karsten. "Institutions of Private Authority in Global Governance Linking Territorial Forms of Self-Regulation." Administration \& Society 33.5 (2001): 555-578.

Rosenau, James N. "Governance in a new global order." Governing globalization: Power, authority and global governance (2002): 70-86. 
Sugden, John, and Alan Tomlinson. "Global power struggles in world football: FIFA and UEFA, 1954-74, and their legacy." The International Journal of the History of Sport 14.2 (1997): 1-25.

Sugden, John and Alan Tomlinson. 2000. 'Football, Ressentiment and Resistance in the Break-up of the former Soviet Union.' Culture, Sport, Society 3(2), 89-108.

Tomlinson, Alan. 2000. 'FIFA and the Men who made it.' Soccer and Society 1(1), 55-71.

Tomlinson, Alan. 2007. 'Lord, don't stop the Carnival: Trinidad and Tobago at the 2006 FIFA World Cup.' Journal of Sport and Social Issues 31(3), 259-282

Włoch, Renata. 2012. 'UEFA as a New Agent of Global Governance: A Case Study of Relations between UEFA and the Polish Government against the Background of the UEFA EURO 2012.' Journal of Sport and Social Issues. DOI: $10.1177 / 0193723512467192$

\section{Online Source}

McCarthy, Niall. 2015. FIFA's Extraordinary Revenue Figures https://www.forbes.com/sites/niallmccarthy/2015/05/27/fifas-extraordinary-revenuefigures-infographic/\#553ff9558234. Retrieved on December 20, 2015 at $22.00 \mathrm{WIB}$

Republika.co.id, 2015. Online Access: http://www.republika.co.id/berita/sepakbola/ligaindonesia/15/06/29/nqpo76k-kemenpora-pssi-dibekukan-karena-tak-patuh. Retrieved on December 20, 2015 at $22.00 \mathrm{WIB}$

Jacobinmag.com, 2015. Online Source: https://www.jacobinmag.com/2015/06/sepp-blatterworld-cup-qatar-charges/. Retrieved on 05 January 2016 at 11:00

Republika.co.id, 2015. Online Source: http://www.republika.co.id/berita/sepakbola/ligaindonesia/15/06/29/nqpo76k-kemenpora-pssi-dibekukan-karena-tak-patuh, Retrieved on 05 January 2016 at 11:00

Bola.Tempo.co, 2015. Online Source:

http://bola.tempo.co/read/news/2015/06/17/099675823/sepak-bola-indonesia-diaturmafia-seperti-apa-praktek-15-tahun-ini. Retrieved on 05 January 2016 at 11:00

Bola.Tempo.co, 2013. Online Source:

http://bola.tempo.co/read/news/2013/12/01/099533682/ditanya-soal-gaji-indra-sjafrimenangis. Retrieved on 05 January 2016 at 11:00

Soccer.sindonews.com, 2016. Online Source:

http://soccer.sindonews.com/read/1016991/58/menpora-diminta-belajar-lagi-soalmekanisme-kompetisi-dan-statuta-1435243521. Retrieved on 05 January 2016 at 11:00 


\section{Short Resume of the Authors}

Indra Kusumawardhana was born in Surabaya on $20^{\text {th }}$ of May 1986 . Indra is permanent lecturer at Department of International Relations "Universitas Pertamina" (Pertamina University) Jakarta. He completed his Bachelor Degree of Humanity and English Literature in Airlangga University on 2010. Thereafter, he studied on Globalization and Strategy in the same University to earn his Master degree in International Relations in 2012. Completing his study in Humanity Science, Indra wrote his final essay about the deconstruction of Christopher Hitchens's atheistic belief in the book of "God is not Great". Then, to obtain his Master degree, he wrote a thesis about "European Union in Crisis: The strengthen of Sovereignty based paradigm in European Union Economic Crisis. Currently, as Doctoral Candidate at Padjadjaran University, he is doing his dissertation research about "Indonesia's Response Towards Vietnam And China to Tackle A Maritime Security Contestation Within Natuna's Territorial Waters Related to The Potential Of "Illegal, Unreported and Unregulated (IUU) Fishing" In the Era of President Joko Widodo". Additionally, his active email address: Kusumawardhana.up@gmail.com/indra15008@mail.unpad.ac.id

Some of his publication can be read here:

Kusumawardhana, Indra. 2013. "European Union in Crisis: Menguatnya Pandangan Berbasis Kedaulatan di dalam Krisis Ekonomi Uni Eropa." Jurnal Hubungan Internasional 6.1.

Kusumawardhana, Indra. 2017. "Understanding the Dynamic of International System Through the Lens of Complex System Approach." Jurnal Hubungan Internasional 10, no. 1: 90-105.

Kusumawardhana, Indra. 2017. "IS THE 'ASEAN ECONOMIC COMMUNITY' UNDER SIEGE? The New Trajectory of the ASEAN Economic Community Within Two MegaRegional Agreements "RCEP" and "TPP". Journal of Indonesian Social Sciences and Humanities 7 (1), 29.

Muhammad Badaruddin is Senior Research Associate at the Center for Politics and Governance Studies (CPGS) of Universitas Bakrie. He completed his first degree in Airlangga University's Communication Science in 2001, and then continued his Postgraduate study in Political Science in University of Indonesia in the same year. In 2006, Badar received scholarship from S. Rajaratnam School of International Studies (RSIS-NTU), Singapore to study MSc on Strategic Studies. Then in 2009, he studied MA on International Political Economy in University of Manchester, England with scholarship from the British Chevening. Completing his study in Communication Science, Badar wrote his final essay about Political Rhetoric of President Abdurrahman Wahid. Then, in RSIS, he wrote a dissertation about Intelligence Reform and Indonesian Democratization, and also wrote about Indonesia's Energy Export Policy for his dissertation in University of Manchester. Currently, he is doing his dissertation research on the Indonesia's Energy Security Strategy in the Padjajaran University. He can be contacted through muhammad.badaruddin@bakrie.ac.id or badarmahfudz@gmail.com

Some of his publication can be read here:

Badaruddin, Muhammad, 2013, "Indonesia-China Energy Trade: Analyzing Global and Domestic Political Economic Significance in Indonesia-China LNG Trade," Journal of ASEAN Studies, Vol. 1, No. 1, pp. 25-40.

Badaruddin, Muhammad, 2015, "Indonesia Rejoining OPEC: Dynamics of the Oil Importer and Exporter Countries," Journal of ASEAN Studies, Vol. 3, No. 2 (2015), pp. 116132. 